\title{
The Failed Growth Economy, Stagnation, and Biophysical Limits to Growth
}

\author{
Kent A. Klitgaard (Corresponding author) \\ Department of Economics and Management, Wells College \\ 170 Main Street, Aurora, New York, 13026, United States \\ Tel: 1-315-364-3231_E-mail:kentk@wells.edu
}

Received: July 20, 2013 Accepted: August 20, 2013 Published: August 31, 2013

doi:10.5296/ijssr.v1i1.4032 URL: http://dx.doi.org/10.5296/ijssr.v1i1.4032

\begin{abstract}
There are many indications that the era of economic degrowth has already begun, despite conscious policy efforts to maintain it. This indicated by a secular decline in the rate of GDP growth for essentially all OECD countries and many developing ones over the second half of the twentieth century. I believe that this phenomenon has occurred because the mature economies of the world have confronted a set of internal, or social, limits driven by the internal dynamics of capital accumulation and by approaching biophysical limits. These patterns are likely to continue. The purpose of this paper is to synthesize the literature on internal limits to capital accumulation and economic growth with the emerging literature on biophysical limits. Growth-oriented mainstream economics is incapable of analyzing adequately the historical conjuncture of the internal and biophysical limits. A study of heterodox political economy and institutional economics is needed in order to understand the transition to sustainability. The paper surveys prior theories of the internal limits to economic growth and synthesizes them with future potential limits imposed by the decrease in availability and increase in cost of high-quality resources, climate change and peak oil.
\end{abstract}

Keywords: secular stagnation, internal limits, biophysical limits, social structure of accumulation, peak oil, climate change

\section{Introduction}

Economic Growth is the Holy Grail of mainstream macroeconomics. Growth developed in the post-World War II United States as an explicit strategy to meet social goals of maintaining employment, providing opportunities, and increasing material standards of living. Periods of faster economic growth resulted in greater levels of poverty reduction and more 
rapid increases in income (Bluestone \& Harrison, 2000). This strategy was successful from the 1940s until the 1970s when economic growth rates began to slow. The pre-1970 potential for growth was based in a unique set of circumstances. Economic and political hegemony, access to plentiful and inexpensive oil, and mediation of competition and labor militancy led to a long era of rising corporate profits. Unfortunately the growth economy is already beginning its decline, and has been since the late 1960s, as measured by growth rates that have been increasing at a decreasing rate.

Table 1. Economic growth rates in the United States by decade

\begin{tabular}{cc}
\hline Decade & Average annual \% GDP growth \\
\hline $1960 \mathrm{~s}$ & 4.4 \\
$1970 \mathrm{~s}$ & 3.3 \\
$1980 \mathrm{~s}$ & 3.0 \\
$1990 \mathrm{~s}$ & 3.2 \\
$2000 \mathrm{~s}$ & 2.4 \\
\hline
\end{tabular}

Source: Foster and Magdoff, 2009.

The fundamental cause of this decline is that the growth economy is subject to three sets of interrelated limits, and there is increasing evidence that human economies are presently facing these limits, whose mechanisms will be explained more fully in the analysis section. The first set of limits, is internal and social, and found in the dynamics of investment and capital accumulation. When these limits are reached the economy stagnates, or exhibits a tendency towards slow growth, either cyclically or over the long term (secularly). A second set of limits exists in the institutional and political processes, and manifest themselves as political impasse and an institutional structure that does not support vigorous capital accumulation. A final set of limits is related to the biophysical capacities of the planet and are seen in such phenomena as declining growth in resources, especially petroleum, and as human induced-climate change.

Reaching these limits will likely have a profound impact at the systemic level, as capitalist economies must grow in order to survive. Driven by competition and the need to reinvest profits, the system is driven by self-expansion (Magdoff \& Foster, 2011). It is difficult to imagine capitalism in the absence of capital accumulation. The growth imperative is even more pressing in a system increasing dominated by finance. Since the 1940s, and the passage of the Employment Act of 1946, economic growth has been the vehicle by which reasonably full employment and stable prices were to be maintained, with varying degrees of success. The end of the age of economic growth will entail a new set of policy mechanisms to attempt to maintain employment and reduce poverty. The result of the historical conjuncture of these internal economic and external biophysical limits results in The Failed Growth Economy: an economy that must produce growth in order to provide profits and employment yet at the same time simply cannot produce this requisite growth. The failed growth economy creates a 
fundamental dilemma. Growth rates of the real economy, measured by percentage changes, have not been sufficiently high to provide for full employment. At the same time cumulative, or absolute, growth has been too high to provide for sustainability as we deplete non-renewable resources, use more annual biomass than the Earth produces, and exceed the assimilative capacity of the atmosphere. We grow too much and too little at the same time.

\subsection{Purpose}

The purpose of this paper is to synthesize the literature on internal limits with the emerging literature on biophysical limits. Neither the neoclassical nor Keynesian varieties of mainstream economics are capable of analyzing adequately the new impacts of the biophysical limits. The newly emerging discipline of ecological economics has made great strides towards understanding that the human economy exists within and is constrained by a finite and non-growing biophysical system. However, at this point, ecological economics lacks a sophisticated understanding of the underlying dynamics of capitalism as a system.

This paper will augment traditional understandings of the economy as an engine of growth with concepts from heterodox political economy and from institutional economics with the biophysical economics approach grounded in energy analysis in order to develop a more sophisticated understanding of the underlying limits to growth. The essay will begin with a critique of mainstream economics, and then develop in detail the interaction of internal economic and institutional limits with the biophysical limits found in nature. After a discussion of some of the implications of the end of the age of economic growth and directions for further research the paper will conclude with some general remarks on directions for change.

\section{The Inadequacies of Mainstream Economics}

Mainstream economics does not address the fundamental question of systemic limits. There are at least four ways mainstream theory fails to understand and come to grips with the notion of limits to growth, let alone the need to achieve a smaller economy with less adverse environmental impact. For the purposes of this essay mainstream economics will be divided into microeconomics and macroeconomics. Microeconomics developed in the late $19^{\text {th }}$ century, largely as an ideal abstraction and theoretical justification for industrial capitalism. Modern macroeconomics, which deals with the aggregate economy, emerged from the wake of the Great Depression, and is largely associated with the work of John Maynard Keynes. Both were built upon the edifice of $19^{\text {th }}$ century classical political economy. Nearly all classical political economists addressed the concepts of limits to growth, and their main focus was upon the process and problems of production and capital accumulation. All used social class as their basic unit of analysis and all, to a varying degree, were engaged in historically specific analysis. Adam Smith saw a stationary state emerging as the natural consequence of economic development based upon the increased productivity spawned by specialization and the division of labor. Malthus saw the growth of the human population relative to the available food supply as the primary limit, while David Ricardo enunciated diminishing marginal returns to agricultural production and restriction of trade as the fundamental cause of economic decline. Karl Marx focused upon the internal contradictions of industrialization 
such as the tendency for the rate of profit to fall and the relative immizeration of the working class. Neoclassical economists changed the focus to the sphere of exchange, the individual, and a quest to provide universal theory applicable to all historical time periods (DeVroey, 1975).

\subsection{Does Mainstream Economics "Work?”}

Mainstream microeconomics emerged at a time when the world was far away from its biophysical limits. Energy was cheap and abundant, and the depletion of one energy source was generally succeeded by a superior source that could improve productive efficiency. Historically the depletion of wood was met by the emergence of coal, and the coal economy was eventually replaced by the petroleum economy. However the idealized vision of the economy was still subject to the internal limits posed by overinvestment and financial speculation. Major industrial depressions occurred in the 1870s and 1890s, just as neoclassical economics was being synthesized. Another decade-long depression characterized the 1930s. From the inability of neoclassical economics to analyze the causes and depths of the depression emerged Keynesian economics. As this paper will argue, Keynesian economics reached its zenith by the late 1960s as another set of internal limits, including the peak of domestic (U.S.) oil production and the phenomenon of stagflation, and the loss of political hegemony. These rendered mainstream Keynesian policies unable to produce economic growth in a new era of economic stagnation.

\subsection{Theoretical Problems with the Traditional View of Economics}

Traditionally the economy is modeled as separate from nature, as self contained and self regulating, and as a perpetual cycle of value and material circulation between firms and households, by means of markets. From a scientific point of view this is not possible because the representation of the economy as a circular flow is as an isolated system. But entropy always increases in an isolated system according to the second law of thermodynamics. From a physical perspective, one cannot assume away material and heat waste in an actual production process. However, in the absence of these assumptions, the sum of factor prices could never equal the value of output, as is required for the system to achieve equilibrium.

Secondly, mainstream economics is grounded in a theory of rational self-regarding individual behavior. Neoclassical behavioral postulates assume that an increase in material consumption increases happiness. But looked at biophysically, increasing consumption is irrational if one considers the availability of cheap energy to run the mass production economy, the magnitude of resource use relative to the annual production of biocapacity (ecological footprint), and the capacity for our sinks to absorb increasing levels of waste. But since a decrease in consumption reduces aggregate demand and sparks a recession, an environmentally rational decision to live within the planet's limits is irrational from the utilitarian perspective.

Third, mainstream economics solves this dilemma by ignoring the very idea of biophysical limits. Microeconomics focuses on individual acquisitive behavior constrained only by limited money income. Physical inputs are magically transformed into money without the 
inconvenience of having to analyze the physical process of work. Powerless but perfectly-informed consumers meet infinitesimally small firms willing to accept no economic profit in the marketplace. Consumers and firms alike respond to small changes in price, and competition drives price down to marginal cost. Markets are both allocatively efficient and self-equilibrating as long as individual maximizers behave rationally. The core of microeconomics is essentially static, or comparative static, with the focus being on the attainment of equilibrium (Gowdy et al., 2010).

Macroeconomics studies aggregate behavior and here is found the fascination with economic growth. Debates between Keynesian liberals and more conservative neoliberals revolve around the best method to achieve growth, not the question of growth itself. The primary debate between neoliberals and Keynesians concerns the level of aggregate demand needed to provide stable levels of investment in productive capacity, while also resulting in stable prices. From the Keynesian perspective aggregate economies are unstable because of uncertainty, and can achieve equilibrium at any level of output, not necessarily at the full employment level. The private investment process, and not the government, is the primary source of uncertainty and banking and finance arise to compensate for this uncertainty in productive investment. From the Keynesian liberal perspective, it is the intervention of the State that enables the proper functioning of market processes. Furthermore the government should be relied upon to provide the needed demand when the private sector cannot do so. Neoliberal philosophy places the responsibility for the reduction of risk and uncertainty in market processes and in self-regulated regulated finance. The neoliberal perspective is based upon a fundamental belief in small government, deregulation and an unbounded faith in an entrepreneurial spirit that will produce sustained growth once freed from the constraints of government regulation and deficit financing. The ideological conflict between these two world views lies behind much of the political impasse that characterizes U.S. politics in the early $21^{\text {st }}$ century.

Finally, neither Keynesian economics, nor neoliberalism, are grounded within a set of biophysical constraints. Unfortunately, the idea that a material economy could grow forever in a finite and non-growing biophysical system is inconsistent with basic science. Indicators such as ecological footprinting show that the world economy is exceeding the biocapacity of the planet to provide resources and absorb wastes by a factor of $50 \%$, with developed and oil-producing nations exhibiting ecological footprints that exceed biocapacity by a factor of five (Global Footprint Network). But if a system is in overshoot already that system cannot grow its way into sustainability. But a reduction in growth plunges the economy into recession. An economy cannot grow and shrink at the same time. Rational behavior on the individual level is irrational at the systemic level, just as rational behavior on ecological level is irrational on the economic level. This dilemma cannot be solved easily, if at all, in the business-as-usual framework of economic growth. It is time for a new set of theories appropriate to a world of rapidly approaching biophysical constraints. 


\subsection{The Contributions of Ecological Economics}

Beginning in the 1980s a new approach developed called ecological economics. The fundamental breakthrough was the idea that the human economy is embedded in a finite and non-growing biophysical system. The economic subsystem must obey the laws of the primary system as regards the flow of energy and its growth is limited by the boundaries of the primary system.

This is a vast improvement over mainstream theory. A great deal of excellent work has been accomplished estimating the size of the economy relative to the limits of the supporting biophysical systems, including studies focused upon the carrying capacity of the planet (Vitousek et al., 1986; Daily \& Ehrlich, 1992; Postel, 1984; Rees \& Wackernagel, 1992), income and product accounting (Daly and Cobb 1989, Cobb and Cobb 1994), and estimates of the value of natural capital and ecosystem services (Costanza et al., 2004). Unfortunately less work has been done assessing the nature of the economy, its inner dynamics, and how it operates as a system. The fundamental ecological economic dilemma is that of a growing economy embedded in a finite and non-growing biophysical system. The assumption of a growing economy is so fundamental to the pre-analytical vision of ecological economics that few ecological economists have devoted their energies to understanding the patterns of growth or structural and institutional changes over time, including periods of stagnation as well as of economic growth. The history of heterodox political economy is comprised of just this focus on the dynamics of accumulation, distribution and institutional change. This tradition can found in the post-World War II growth theorists, by the Monthly Review School, and by the Social Structure of Accumulation theorists. The focus of these theories has been upon internal limits to growth. Rarely were external, biophysical, limits integrated into the discussion of economic growth and decline upon workers and social structures. If we as a society are going to survive and prosper we will need to learn how learn to live within the planet's biophysical limits. We will need to draw our energy from renewable solar flow rather than limited terrestrial stocks subject to depletion. It will be exceedingly difficult to maintain or improve human welfare while simultaneously reducing the flow of matter and energy through a finite and non-growing system. To accomplish this, without perpetuating the worst aspects of the failed growth economy: chronic unemployment, poverty, and lack of opportunity, is a difficult endeavor. It should begin with an understanding of the dynamics of the growth economy itself. This paper begins just such a synthesis.

\section{Analysis of the Issues Surrounding the Limits to Growth}

This section will survey and review the literature and empirical evidence concerning the limits to growth. The first section will focus on internal limits to growth found in the investment process and culminate with the enunciation of the stagnation thesis. The second section will focus on the theories of the social structure of accumulation, while the final section synthesizes theories of internal limits to growth with external or biophysical limits. 


\subsection{Internal Limits to Growth}

An emphasis on economic growth in the United States emerged only in the latter stage of the New Deal. The early New Deal was about rescue and recovery. At the time many of Roosevelt's economic advisors were committed economic planners, and their visions were operationalized in the National Industrial Recovery Act. Chronic excess capacity and lack of sufficient aggregate demand were to be addressed by rationally planning the reduction of capacity and output. The experiment in consciously reducing the size of the economy ended with the Supreme Court decision in Schechter Poultry Corporation vs. United States, in which the NIRA was declared unconstitutional (Kennedy, 1999). Growth in industrial capacity once again took precedence during the Second World War.

\subsubsection{The Post-War Growth Theorists}

During the second downturn of the Great Depression (1937-39) the American Keynesian Alvin Hansen enunciated a theory of secular stagnation. Hansen argued that adequate investment outlays are needed to sustain full employment levels of income. Because these investment outlets are difficult to find in a mature economy deficit spending by the government was required as a permanent feature of the economy.

Mature economies also exhibit slower rates of population growth. In earlier periods population was the driving force behind investments in residential building, territorial expansion, mass consumption, and the expansion of railroads and public utilities. Hansen contended that there was neither new rich land to be occupied, nor new innovations on par with those of the immature and rapidly growing $19^{\text {th }}$ century economy. This earlier century gave birth to the industrial revolution and the corresponding increase in investments in plant and equipment. Then came a period of "readjustment and relative stagnation" (Hansen, 1939:314). This period of stagnation was followed by the great expenditures of the railroad age, which themselves reached saturation. This was followed by the ages of electrification and the automobile which provided a whole host of opportunities for investment in related industries as well.

Hansen concluded that new opportunities sufficient to utilize fully the flow of savings would be difficult to find in the mature economy. Hence the dilemma was one of long-term (or secular) stagnation and the very stability of the growth-based economy, not just cyclical downturns and periodic declines in living standards. He advocated that the government become an investment banker rather than simply a lender of last resort or a short-term pump primer.

Hansen's argument was augmented by the work of Evesy Domar and R'oy Harrod. Domar posited that the percentage of the labor force employed depends upon the ratio of national income and productive capacity. His key insight was to point out what he called "the dual nature of investment." Investment creates income and employment by means of a multiplier effect, while simultaneously creating additional productive capacity that increases labor productivity and output. The additional capacity must be utilized to maintain employment. If income and employment are to rise a growing level of expenditures must be targeted towards 
investment. But this additional investment must be absorbed through ever increasing expenditures. This is the essence of the failed growth economy, as regards internal limits If final demand (consumption + investment) grows at a slower rate than in previous time periods, investment growth will actually decline by means of an accelerator process The decline in investment plunges the economy into depression, thereby reducing final demand. The growth economy can only transcend its internal limits by accelerating growth in investment. This is not possible, given that the investment must be matched by increased spending. However the increase in the propensity to save needed to generate the funds for investment entails a reduction in the propensity to consume. The lower propensity to consumer creates a smaller multiplier effect and slower growth in final demand.

Indeed, it is difficult enough to keep investment at some reasonably high level year after year, but the requirement that is always be rising is not likely to be met for any considerable length of time (Domar, 1947: 47).

The unused capital goods appear as excess capacity and the existence of this unused capacity provides a further limit to new investment and economic growth. The degree to which excess capacity affects investment depends upon the structure of industry. A competitive economy that is changing rapidly in terms of technology is relatively unaffected by excess capacity. However unused capacity presents a serious threat to new investment in industries that are monopolized and financially connected. If more is invested in the present period even a greater amount will be needed to maintain full employment in the next period. It is unlikely that the increase in income will more than compensate for the increase in capacity because the increase in income is temporary while the increase in capacity is longer lived. Consequently, the empirical evidence on investment shows volatile fluctuations in the rate of change in investment over time, rather than steady growth.

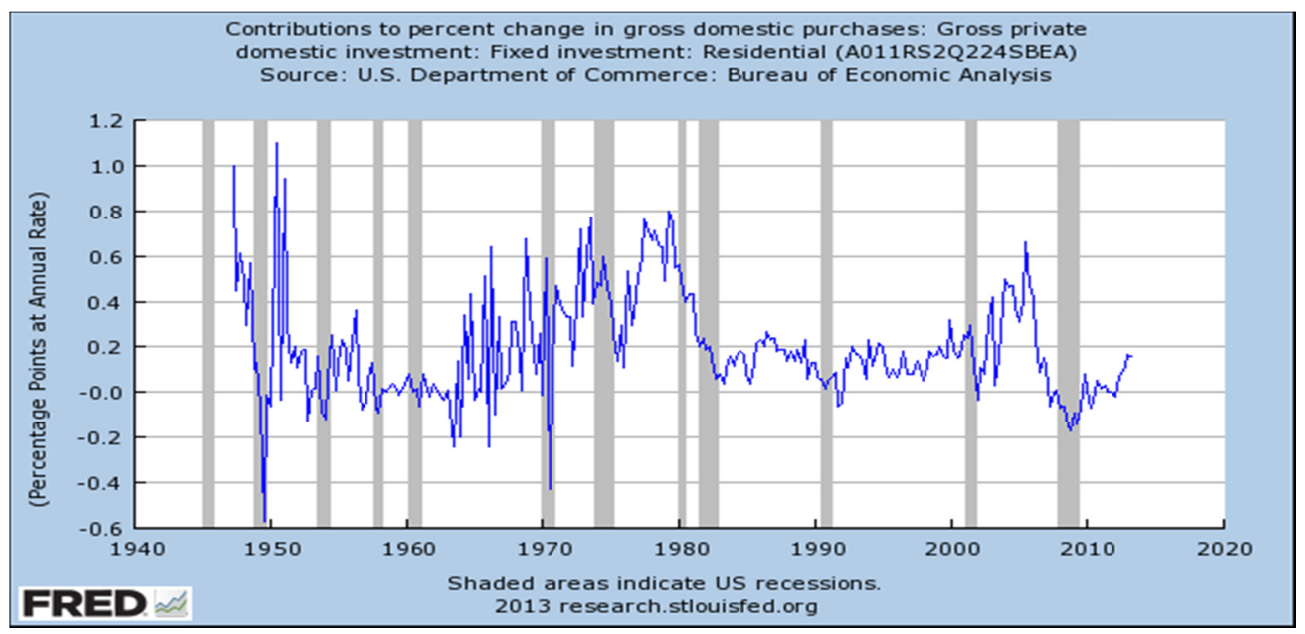

Figure 1. Percentage change in U.S. gross private domestic investment

In a similar vein British economist Roy Harrod argued that a conflict existed between the actual growth rate $\left(G_{A}\right)$ and the warranted growth rate $\left(G_{w}\right)$, determined by the ratio of savings to the capital-output ratio, and defined as the growth rate which left investors 
satisfied they had invested the correct amount If the actual growth rate exceeded the warranted one, explosive oscillations of inflation could occur. If the opposite were true, the economy could plunge into recession, in a classic positive feedback mechanism The unlikely event that they would equal or converge led Harrod to call a trajectory of smooth growth the "razor's edge" (Harrod, 1939; Shackle, 1967). The theories of both Harrod and Domar depended upon savings as the source of funds for investment. The institutional structure of the post-war world separated the investment banking (speculation and securities trading) functions from those of commercial banking (taking deposits and making loans). Golden age growth theory viewed banking mostly in a subservient loan-making lens. This was to change in the neoliberal era.

\subsubsection{Monopoly Capitalism and the Monthly Review School}

In the years leading up to their publication of Monopoly Capital in 1966 Paul Baran and Paul Sweezy surveyed and synthesized a great deal of literature, from classical Marxism to Keynesian growth theory to arrive at the most complete modern statement of "the stagnation thesis." They asserted that the economy had become dominated by giant corporations, or oligopolies, which compete co-respectively by means of cutting costs and increasing market share, not by means of reducing prices.

Historically in the United States, that rise of the oligopoly was achieved by means of mergers and consolidations. When prices fell faster than costs in the depressions of the late 1890s profits declined and price competition proved ruinous to companies, especially those with large investments in long-lived fixed capital, such as railroads and basic industries. Standard economic theory tells us that competitive markets yield an equilibrium price that tends towards marginal cost. If a company with large investments in long-lived fixed capital can only charge the cost of providing one more unit of output they will never generate the revenues needed to repay the cost of the original investment. The preferred solutions were to eliminate price competition and better control costs (Perelman, 2006). By this time the dominant business was that of the large-scale corporation or oligopoly. Merger movements did not stop with the end of the $19^{\text {th }}$ century. Four additional movements occurred over the course of the $20^{\text {th }}$ century, from the conglomerate mergers of the 1960 s to the energy-related mergers of the 1980s to the financial and cross-border mergers of the end of the century to the early $21^{\text {st }}$ century (Hall $\&$ Klitgaard, 2011).

In Monopoly Capital Paul Baran and Paul Sweezy enunciated the hypothesis that monopoly capitalism exhibited a rising economic surplus, defined as the difference in the value of the output (GNP) and the cost of producing it. The source of the rising surplus is found in the nature of oligopoly competition. Technological changes and improvements in efficiency reduce cost and increase potential output, while tacit agreements among oligopolists not to cut prices combine to increase the economic surplus. The fundamental economic problem in the monopoly capitalist era is the inability to absorb, or find adequate spending outlets for, the rising economic surplus. This rising surplus leaves its statistical trace as excess capacity and unemployment. Baran and Sweezy then go on to explain the internal mechanisms by 
which surplus can be absorbed. Surplus can be invested, but investment alone is unlikely to absorb fully the surplus.

Their analysis of investment follows from Domar. Investment alone is unlikely to absorb the surplus because additional productive capacity, and therefore greater potential surplus is created by the act of investment spending Surplus can be consumed, but even with the development of the sales effort in the 1950s--from planned obsolescence to the explosion of advertising--consumption cannot adequately absorb a rising surplus either. The ability of civilian government to consume adequately the surplus is constrained by the impasse of the political process. Government projects such as hospitals that compete effectively with the private sector are discouraged, and funding the development of alternatives, such as fossil-fuel driven automobiles, would compromise the profits of many important industries. The final option is to simply waste the surplus. Baran and Sweezy focused mainly on the military but in today's climate one must also consider the United States' fossil-fuel based transportation system, our approach to health care and our crumbling, yet expensive, system of public schools. In the end the regular, internal mechanisms are incapabile of sustaining the absorption of economic surplus. Therefore the economy stagnates in the sense that it generates actual income levels that are beneath potential income levels. This results in chronic excess capacity and unemployment. Consequently the tendency of a mature, monopoly capitalist economy is towards stagnation, not growth.

The theoretical task became one of explaining periods of economic growth, not periodic downturns, which they did by relying on the concept of epoch-making innovation. Such innovations not only absorb tremendous amounts of investment capital themselves but fundamentally transform the structure of industry by creating myriad ancillary industries that also utilize investment capital. They develop further the three innovations cited in Hansen (1938): the steam engine; the railroad; and the automobile. From a biophysical point of view all these innovations transformed the structure of industry and society by requiring, and stimulating the search for, cheap fossil energy. The automobile helped create the demand for suburban housing, drive-ins, repair shops, the interstate highway system, and shopping malls, absorbing sufficient economic surplus to provide for a prolonged period of prosperity, but also setting in motion unsustainable housing structures and transportation systems. The second factor that absorbed sufficient surplus was war and its aftermath. The Second World War was the largest public works program in American history. Unemployment, which stood at $17.9 \%$ in 1939 , fell to $1 \%$ by 1944 (Baran \& Sweezy, 1966). The aftermath of the war led to the Bretton Woods Accords, the Marshall Plan and a long period of U.S. hegemony. The end of this hegemony, along with the collapse of the Bretton Woods Accords in the 1970 signaled the end of the growth economy, as well as the success of liberal growth strategies.

In summary, a monopolized economy tends towards slow economic growth due to the inability to absorb economic surplus. The tendency towards stagnation is kept at bay essentially by war, waste, and conspicuous consumption. The rise of capitalism was based not on efficiency but upon fossil energy, industrial revolutions, mechanized chemical agriculture and upon a rapid rise in the world's population. Since increases in output without increases in consumption manifest themselves as excess capacity and unemployment, capitalism depends 
upon ever greater quantities of energy, material inputs and waste. In the long term capitalism is on a collision course with a sustainable economy and society (Magdoff \& Sweezy, 1989).

\subsubsection{Monopoly Finance Capitalism and the Limits to Growth}

In a 1991 retrospective on Monopoly Capital Sweezy criticized himself and Baran for neglecting the financial dimensions of a mature capitalist economy. He contended that before the 1980s both mainstream and Marxist economists the treated capital accumulation as a matter of adding to the stock of capital goods. "But in reality this is only one aspect of the process. Accumulation is also a matter of adding to the stock of financial assets." (Sweezy, 1991: 56). In the 1980's Sweezy, in collaboration with Harry Magdoff, produced a series of articles on "the financial explosion."

The neoliberal economy is also a financialized economy, and has been since the dawn of the corporate era. The merger movement of the early $20^{\text {th }}$ century was driven by bank consolidations of industrial capital, and periods of speculative excess were common at the end of cyclical booms However, by the 1980s speculative excess occurred in a prolonged period of slow growth and the explosion of the financial economy in the 1980s was a symptom of the overall stagnation of the real economy. Instead of being a parasitical usurper of funds that would have naturally lead to added investment in productive capacity the rise of the financial services sector has been the primary means by which the stagnation of the real economy has been kept at bay (Magdoff \& Sweezy, 1985). In addition the financial system has not simply grown, but has fundamentally transformed the economy. In the transformed state, termed "Monopoly Finance Capitalism" the expanded, and increasingly independent, financial services sector has come to claim the dominant share of the systems profits, increase the offering of increasingly complex securities, and has become the nation's largest debt-holding sector. The financial sector, now freed from its subordinate role as a lender to industry, exists primarily to create ever more complex derivative securities in order to seek out potential opportunities for growth and profit. However, the rise of the financial economy is subject to its own limits, and in the end cannot overcome the inherent stagnationist tendency of mature capitalism. As the real economy has stagnated, financial activity and the expansion of debt have come to represent a growing share of total profits and a rising percent of the components of income. Since cost-cutting strategies entail the reduction of wage growth, the expansion of market share. More output can only be sold to a population with declining incomes by means of the expansion of debt. By 2007 total debt was nearly three and one half times GDP. Debt for all sectors increased, and the financial sector expanded 160-fold from 1970 to 2007. 
Table 2. Debt and GDP (trillions of dollars)

\begin{tabular}{lllllll}
\hline Year & GDP & Total Debt & Household & $\begin{array}{l}\text { Financial } \\
\text { Firm }\end{array}$ & $\begin{array}{l}\text { Non-fin } \\
\text { Firm }\end{array}$ & Gov’t \\
\hline 1970 & 1.0 & 1.5 & 0.5 & 0.1 & 0.5 & 0.4 \\
1980 & 2.7 & 4.5 & 1.4 & 0.6 & 1.5 & 1.1 \\
1990 & 5.8 & 13.5 & 3.6 & 2.6 & 3.7 & 3.5 \\
2000 & 9.8 & 26.3 & 7.0 & 8.1 & 6.6 & 4.6 \\
2007 & 13.8 & 47.7 & 13.8 & 16.0 & 10.6 & 7.3 \\
\hline
\end{tabular}

Source: Foster and Magdoff, 2009.

At some point the limited income will also limit the expansion of debt, as will the rising inequality in the distribution of those incomes. This was manifest, over the course of the last year, starting in the US housing sector and extending to the debt pressures felt by myriad mature economies. The most rapid increase occurred in the financial sector. Despite trillions of dollars of bailout funds banks have curtailed their lending and corporations continue to sit upon a sea of cash. Economic growth in the aftermath of the financial crisis languishes in the $1-2 \%$ range while most of Europe is mired in economic decline.

A great deal of money capital will be needed to decarbonize the current economy and rebuild one on augmented solar flow. How this will be accomplished on a fragile and speculative financial structure, especially when new technologies are often unprofitable (witness the bankruptcy of Solyndra), needs considerable research. How it can be accomplished in the current political climate is also an important matter.

\subsubsection{Political Limits to Growth and the Social Structure of Accumulation}

An institutional approach called the Social Structure of Accumulation (ISSA) hypothesized that the functioning of markets is embedded within a context of social institutions. Just like embedding the economy in a finite and non-growing biophysical system forces us to think about the limits of the primary system, embedding the functioning of markets within a social system forces one to think about the interaction of markets with the broader set of institutions. Moreover the institutions contain contradictory forces which assert themselves as long periods of time pass.

The social structure of accumulation built in the aftermath of the depression of the 1890s was based on homogenization of the labor, the appropriation of the gains of productivity by capital, and limited involvement of the state. It collapsed in the Great Depression. A new social structure was built upon four pillars of postwar prosperity such as the economic and military hegemony of the United States, limited competition, unionized labor, and a positive state. A uniting of citizens behind an agenda of growth lessened the pressure for the redistribution of income. Economic growth rates remained strong until the early 1970s, when internal and external forces combined to cause the decay of the postwar SSA. The costs of maintaining a complex empire began to mount and add to the country's balance of payments deficit, and the decline of US power was punctuated by a military defeat in Vietnam. 
Moreover the domestic supply of oil peaked in 1970 and in 1973 the country was subjected to significant escalations in the price of oil and gasoline. The Bretton Woods Accords, predicated on the willingness of the US to convert currency claims to gold at $\$ 35$ per ounce, collapsed when volume of claims exceeded the gold stock. Facing the loss of profits linked to the decline of US hegemony, profits began to fall and US corporations could no longer "afford" a limited capital labor accord. The costs of military spending in conjunction with civilian spending necessary to maintain the capital citizen accord at a time of high employment produced demand-pull inflation. This combined with the cost-push inflation driven by resource price increases, union contracts with cost of living adjustments, and the administered pricing of oligopolies to produce simultaneous inflation and recession. Moreover Europe and Japan began to compete effectively with the United States on world markets, increasing the pressure upon profits. The postwar SSA simply could not withstand the pressures of the stagflation era and began to decay. Productivity growth declined from $2.7 \%$ per year in the 1950 s to $0.3 \%$ per year in the 1970 s, while GNP growth declined accordingly, from $4 \%$ in the 1950 s and 1960 s to $2.6 \%$ per year in the 1980 s (Bowles, 1990:). A period of impasse ensued for nearly a decade. A new SSA, termed neoliberalism, was constructed in the early 1980 in The United Kingdom and the United States, with the rise to power of conservatives Margaret Thatcher and Ronald Reagan.

Economist David Kotz argues that by the late 1980s a core set of neoliberal institutions has been sufficiently implemented to establish a new SSA. These include 1) removal of international barriers to the free movement of commodities and capital; 2) the withdrawal of the state from regulatory activity; 3) privatization of state enterprises and public services; 4) a shift to regressive taxation; 5) the end of the capital labor accord; 6) the replacement of co-respective oligopoly behavior by renewed competition; and 7) an faith in entrepreneurial spirit and free market ideology (Kotz, 2010).

However the internal dynamics and contradictions of the neoliberal SSA have not manifested themselves as rapid and sustained capital accumulation, as its advocates believe it should. The rate of GDP growth in the neoliberal SSA (1990-2007) was 2.99\% per year, a rate not significantly higher than the growth rate of $2.93 \%$ during the decay of the postwar SSA.

Has the United States reached the limits of increasing economic growth by means of fiscal policy and monetary policy? Perhaps yes, for once interest rates have fallen to virtually zero there are few policy options. Quantitative easing has not resulted in dramatic decreases in unemployment or increases in fixed investment. Rather the low-interest money has found its way into the stock market, whose prices have nearly doubled from the 2009 trough until the summer of 2013. Yet in July of 2013 hints by Federal Reserve Chair Bernanke that the economy was performing sufficiently to allow the end of quantitative easing caused stock prices to plummet for a few days and remain volatile thereafter. Furthermore, domestic political opposition and fear among the international financial community limits further deficit spending. 


\subsection{External Biophysical Limits to Growth}

Productivity increases in manufacturing have largely been the result of utilizing increasing quantities of cheap oil, and internet-associated productivity increases depend on an adequate supply of electricity (Cleveland, et al. 1984). The advent of peak oil will raise these input prices with two potentially adverse results. On the supply side rising oil prices (and consequently rising prices for food, chemicals, transportation, etc) will likely lead to the reemergence of cost-push inflation on the basis of falling energy returns on investment (EROI), assuming no cost-effective substitute can be found for liquid petroleum on a timely basis. It is very difficult to fight cost-push inflation by means of contractionary monetary policy, as interest charges are themselves components of costs. Furthermore, oil is denominated in dollars and any structural weakening of the US economy, by means of inflation, further exacerbates the increase in oil prices.

Increase in oil prices can have demand-side effects as well. As oil prices rise, the stocks of petrodollars found in sovereign wealth funds will need to find an investment outlet. If the country follows an accommodating monetary policy, these funds will look for higher long-term rates of returns than can be found in Treasury Bonds, potentially reinflating another speculative bubble. If the nation runs a contractionary monetary policy the risk of stagflation becomes more probable. Furthermore peak oil threatens the demand side of the equation by reducing discretionary income. Hall, Powers and Schoenberg assert that paying for the same quantity of energy at higher prices will reduce discretionary income.

If the Earth's biophysical system were a simple one, the economic system could possibly adapt through the usual means of technological change and productivity increases. While technological change in the oil extraction industry has not found significant quantities of new liquid petroleum, the new techniques such as horizontal drilling and hydraulic fracturing have allowed the extraction of hydrocarbons previously found uneconomical to acquire, albeit with the increased use of energy to extract them. Furthermore, as prices for conventional oil have risen, sources such as bitumen found in Canadian oil sands, present themselves as economically feasible sources. Natural gas prices have fallen consistently in the past half-decade as fractured gas appears on the world market. Unfortunately the Earth's system is not simple. Rather it is a complex system full of positive feedbacks. One of the most important is the planet's climate. In 1992 the United Nations Framework Convention on Climate Change resolved to stabilize atmospheric greenhouse gases (GHGs) at a level that would avoid dangerous anthropogenic interference with the planet's climate (United Nations, 1992). Since then a cornucopia of scientific papers have emerged to classify what is "dangerous." The scientific consensus is that a doubling of GHGs will produce a $3{ }^{\circ} \mathrm{C}$ increase in the Earth's average temperature. Given the lengthy residence time of carbon dioxide in the atmosphere (approximately 100 years) there are already sufficient GHGs in the "pipeline" to produce at least a 2.4 degree warming. At current rates of emission increase of $2 \%$ per year, that doubling could occur in less than 40 years (Hansen et al., 2007). James Hansen of NASA-Goddard Institute for Space Studies concludes that if we were to burn all the available hydrocarbons extractable under current technologies, the carbon emitted into the atmosphere (approximately 3000 Gigatons) would be sufficient to melt the glaciers of Greenland and 


\section{I Macrothink}

Antarctica, thereby producing a sea-level rise of up to 75 meters, a catastrophic loss of biodiversity and a human tragedy of climate refugees (Hansen, 2009).

Few solutions to the problem of climate change exist, as there is sufficient carbon dioxide in the atmosphere to produce at least $2-3^{\circ}$ of warming by the end of the century. Moreover, they all entail slowing the absolute accumulation of greenhouse gases in the atmosphere, not just slowing the rate of emissions. The fundamental question must be asked. Can the present economic system that is defined as self-expanding value by means of capital accumulation exist as a non-growing system? If not, how can we avoid the potentially catastrophic climate change that will occur when the tipping points are reached? The world's climate delegates met in December 2009 with the expressed goals of keeping emission below the level (roughly $450 \mathrm{ppm}$ ) that would produce an average temperature increase of no more than $2^{\circ} \mathrm{C}$. The convention was unable to produce any binding accords, as any accord to limit carbon emissions also threatens to limit economic growth.

\section{Discussion}

Within the present framework sustainability will be difficult, if not impossible, to achieve. The growth that affects the environment is cumulative growth. At the same time, final demand needs to increase at an increasing rate in order to bring forth further increases in investment, the engine that drives the macroeconomy. The fundamental dilemma of the failed growth economy is that cumulative growth in carbon dioxide emissions, GDP, and consumption have increased exponentially, thereby pressuring the finite and non-growing biophysical limits. At the same time percentage change and investment is extremely volatile and exhibits, along with the percentage change in Real GDP, a downward trend leading to a stagnant economy in the long term. Any attempt to increase growth within the confines of the present institutional and economic structure threatens to make resource depletion and climate change worse. Any attempt to reduce carbon emissions by reducing consumption and waste threatens the viability of the economy.

The present situation can only be exacerbated by the expected long-term increases in oil prices that accompany the post-peak declines in the Energy Return on Investment. Recent history shows a close correlation between oil price spikes and the lagged onset of recession. This phenomenon appeared in the data when oil price increases were essentially cyclical and political. But the advent of peak oil means the causes will become more secular and geological. 




Figure 2. Oil Prices and recessions

These events of the near future will only exacerbate the already-existing stagnation tendencies found in the internal dynamics of the monopolized economy. Neither Keynesian liberal nor neoliberal governments have much choice other than to pursue growth policies in order to counter the rising unemployment which is the "statistical trace" of stagnation. Yet there will come a time when all the traditional tools, from expansionary fiscal and monetary policy to outright bailout may no longer work.

\section{Conclusion}

The fundamental dilemma of the failed growth economy: that growth is simultaneously too fast and too slow, cannot be addressed adequately in the context of a set of institutional arrangements that rely on economic growth to meet basic human needs of employment and freedom from poverty. We must find theories that are consistent with the basic laws of science and do not sacrifice human dignity to a failed system in which a reduction in economic growth translates into stagnation and unemployment. This system can be constructed on neither neoliberal nor Keynesian growth-based principles. One method of finding such a future lies in biophysical economics. We need to understand the energy basis of economic activity and construct a new social structure that is coherent, long lasting and based on regulation and a just distribution of income, while maintaining a scale of energy use and carbon emissions that lies within the earth's biophysical limits. Mainstream economics does not possess the tools to do this. Biophysical economics, grounded in basic science and a solid understanding of the capital accumulation process offers a viable alternative.

\section{Acknowledgements}

I would like to thank Deborah York, Lisi Krall, and Charles A.S. Hall for their helpful comments and support.

\section{References}

Baran, P., \& Sweezy, P. (1966). Monopoly Capital. New York: Monthly Review Press.

Bluestone, B., \& Harrison, B. (2000). Growing Prosperity. Boston: Houghton-Mifflin. 


\section{Macrothink}

International Journal of Social Science Research

ISSN 2327-5510

2013, Vol. 1, No. 1

Bowles, S., Gordon, D., \&Weisskopf, T. (1990). After the Wasteland. Armonk, New York: M.E. Sharpe.

Cleveland, C., Costanza, R., Hall, C. A. S., \& Kaufmann, R. (1984). Energy and the U.S. economy: A biophysical approach. Science, 211, 576-579.

Cobb, C., \& Cobb, J. (1994). The Green National Product. Landham, MD: University Press of America.

Costanza, R., d'Arge, R., deGroot, R., Farber, S., Grasso, M., Hannon, B., ... van den Belt. (1997). The value of ecosystem services and natural capital. Nature, 387, 253-260. http://dx.doi.org/10.1038/387253a0

Daily, G. C., \& Ehrlich, P. R. (1992). Population, sustainability, and the earth's carrying capacity.” BioScience, 42(10), 761-771. http://dx.doi.org/10.2307/1311995

Daly, H., \& Cobb, J. (1989). For the Common Good. Boston: Beacon Presis.

DeVroey, M. (1975). The transition from classical to neoclassical economics: A scientific revolution. Journal of Economic Issues, 9(3), 415-439.

Domar, E. (1947). Expansion and employment. American Economic Review, 37(1), 34-55.

Foster, J. B., \& Magdoff, F. (2009). The Great Financial Crisis. New York: Monthly Review Press.

Global Footprint Network. (n.d.). Footprint of nations. Oakland, CA. Retrieved from http://www.footprint.org

Gowdy, J., Hall, C. A. S., Klitgaard, K., \& Krall, L. (2010). The end of faith-based economics. The Corporate Examiner, 37(4-5), 5-11.

Hall, C. A. S., \& Klitgaard, K. (2011). Energy and the Wealth of Nations. New York: Springer.

Hansen, A. (1938). Full Recovery or Stagnation? New York: W. W. Norton and Company.

Hansen, J. (2009). Storms of My Grandchildren. New York: Bloomsbury.

Hansen, J. M., Sato, R., Ruedy, P., Kharecha, A., Lacis, R., Miller, L., ... Zhang, S. (2007). Dangerous human-made interference with climate: a GISS Model E study. Atmospheric Chemistry and Physics, 7, 2287-2312. http://dx.doi.org/10.5194/acp-7-2287-2007

Harrod, R. (1939). An essay in dynamic theory. Economic Journal, 49(March), 14-33. http://dx.doi.org/10.2307/2225181

Kennedy, D. (1999). Freedom from Fear. Oxford and New York: Oxford University Press.

Kotz, D. (2010). Financialization and neoliberalism. In G. Teeple \& S. McBride (Eds.), Relations of Global Power: Neoliberal Order and Disorder (pp. 1-18). Toronto: University of Toronto Press. 


\section{Macrothink}

International Journal of Social Science Research

ISSN 2327-5510 2013, Vol. 1, No. 1

Magdoff, F., \& Foster, J. B. (2011). What Every Environmentalist Needs to Know About Capitalism. New York: Monthly Review Press.

Magdoff, H., \& Sweezy, P. (1989). Capitalism and the environment. Monthly Review, 41(2), $1-10$.

Magdoff, H., \& Sweezy, P. (1985). The financial explosion. Monthly Review, 37(7), 1-10.

Perelman, M. (2006). Railroading Economics. New York: Monthly Review Press.

Postel, S. (1994). Carrying capacity: The earth's bottom line. In L. Brown (Ed), State of the World (pp. 3-21). New York: W. W. Norton and Company.

Rees, W., \& Wackernagel, M. (1992). Ecological footprint. In A. M. Jansson (Ed), Investing in Natural Capital. St. Lucie, Florida: Island Press.

Shackle, G. L. S. (1967). The Years of High Theory. Cambridge: Cambridge University Press.

Sweezy, P. (1991). Monopoly Capital after 25 years. Monthly Review, 43(7), 52-57.

United Nations. (1992). United Nations framework convention on climate change. New York. Retrieved from http://www.unfccc.int

Vitousek, P., Ehrlich, P. R., Ehrlich, A. H., \& Matson, P. A. (1986). Human appropriation of the products of photosynthesis. BioScience, 36(6), 368-373. http://dx.doi.org/10.2307/1310258

Wolfson, M., \& Kotz, D. (2010). Global neoliberalism and the contemporary social structure of accumulation. In T. McDonough, M. Reich, \& D. Kotz (Eds.), Contemporary Capitalism and Its Crises (pp. 72-90). Cambridge: Cambridge University Press.

\section{Copyright Disclaimer}

Copyright reserved by the author(s).

This article is an open-access article distributed under the terms and conditions of the Creative Commons Attribution license (http://creativecommons.org/licenses/by/3.0/). 